International Journal of Agriculture, Environment and Bioresearch

Vol. 06, No. 02; 2021

ISSN: $2456-8643$

\title{
OPTIMIZATION OF REPRODUCTIVE PAPUYU FISH (Anabas testudineus Bloch) WITH ADDITION OF B-GLUCAN AND VITAMIN E
}

\author{
Hamidun Agus Sapar ${ }^{1}$, Untung Bijaksana2 and Indira Fitriliyani ${ }^{2}$ \\ ${ }^{1}$ Student of Magister Program of Fishery, University of Lambung Mangkurat, Indonesia \\ ${ }^{2}$ Faculty of Fishery and Marine, Universitas of Lambung Mangkurat, Indonesia
}

https://doi.org/10.35410/IJAEB.2021.5620

\begin{abstract}
The natural reproductive cycle of swamp water fish, one of which is papuyu fish, becomes unproductive when entering the dry season because there is a total catch in the "wells" or "beje" simultaneously and without realizing it, these papuyu fish are $90 \%$ gonad ripe. This research was conducted with the aim of assessing the performance of $\beta$-glucan and vitamin $E$ in improving the reproductive quality of papuyu fish (Anabas testudineus Bloch). The maintenance of papuyu broodfish was carried out for 20 days with commercial feed mixed with $10 \mathrm{ml} / \mathrm{kg}$ of $\beta$-glucan and Vitamin E $150 \mathrm{mg} / \mathrm{kg}$ of feed for treatment (A) and commercial feed for treatment (B) Feeding twice a day in the morning 8:00 a.m. and 5:00 p.m. with a dose of 5\% of the body weight of the fish. The method used in this study was the comparative analysis method using the $\mathrm{T}$ test. The results showed that the addition of $\beta$-Glucan and vitamin $\mathrm{E}$ mixed in the feed had a significant effect on the percentage of somatic gonado index (IGS), but had no significant effect on the hepato index. somatic (IHS)..
\end{abstract}

Keywords: Papuyu Fish, B-glucan, Vitamin E, Reproduction.

\section{INTRODUCTION}

Papuyu fish is a swamp fish that is very popular with the people of Banjar (South Kalimantan) because in addition to its delicious taste and its high economic value compared to other types of fish. Due to the presence of this fish is seasonal, in certain seasons the production is abundant in nature, while in other seasons this fish is difficult to find so the price is relatively expensive.

The natural reproductive cycle of swamp water fish, one of which is papuyu fish, becomes unproductive when entering the dry season because simultaneously there is a total fishing in "wells" or "beje" and without realizing it, these papuyu fish are 90\% gonad ripe (Bijaksana, 2006 ). Natural fish traps in swamp waters are known as "beje" (Bijaksana, 2010). One of the reasons for this is the decline in population or the increasing size of the papuyu fish caught at this time. At the time of the fishing season (the peak of the dry season) most of the caught are papuyu fish in a state of gonad maturity development. It is very likely that if this happens continuously, the papuyu fish that are caught will have the greater the size.

Papuyu fish is also classified as a type of fish that has not been perfectly domesticated where this fish has a higher stress level, so it is necessary to know how to increase fish immunity by giving immunostimulants, it is hoped that as an effective way to reduce stress levels in fish is using 
Vol. 06, No. 02; 2021

ISSN: $2456-8643$

natural ingredients as immunostimulants.

One way to obtain optimal fish hatchery results is to improve reproductive performance, by increasing or stimulating the immune system and through improving the nutritional quality of parent feed, nutrient elements that must be present in parent feed, including vitamins and fatty acids (Cholik et al., 2005) ). The results showed that giving $\beta$-glucan could increase immunity. $\beta$ glucan as an immunostimulant can be used as an alternative in cultivation. There is a need for more studies regarding the use of $\beta$-glucan as an imonostimulant to increase the non-specific immune system in fish is very necessary in an effort to reduce stress levels in fish. Efforts are also made to improve the quality and production of fish through the improvement of broodfish, namely by providing quality feed to broodfish that will determine the success of reproduction. One way that can be done in providing quality feed is through the provision of vitamin $\mathrm{E}$ supplementation in the feed (Mokoginta et al., 2000). Napitu et al. (2013) revealed that vitamin E has a very important role in increasing fish reproduction because vitamin $\mathrm{E}$ functions as an antioxidant that can maintain the presence of fatty acids and prevent fat oxidation in cell membranes and can accelerate the secretion of reproductive hormones.

Cultivation development is very dependent on the availability of seeds that meet the timeliness, quality and quantity. Seeds can be produced continuously if they are supported by the availability of mature parents with good egg quality. However, the current problem for papuyu fish is a type of fish that has not been fully domesticated so that it has a higher stress level. Therefore, it is necessary to look for alternative solutions to problems, for example by giving immunostimulants to papuyu brood fish which hopefully can reduce stress levels and also need to find alternatives to improve the quality of the broodstock, especially improving the quality of parent reproduction so that it can be more optimal.

This research was conducted with the aim of assessing the performance of $\beta$-glucan and vitamin E in improving the reproductive quality of papuyu fish (Anabas testudineus Bloch).

\section{RESEARCH METHOD}

The papuyu fish broodstock used in this study came from the city of Banjarbaru as a result of hatchery. The number of broodstock needed as many as 50 female broods who are still young have never been spawned but the fish are already in a state of gonad maturation development as shown in the description of the results from observations of the female parent's gonad histology test.

The artificial feed that will be used in this research is commercial feed with $32 \%$ protein and according to the age and mouth opening of the fish. Before being given to fish, the test feed is first mixed with $10 \mathrm{ml} / \mathrm{kg}$ of $\beta$-Glucan which has been diluted with $100 \mathrm{ml}$ water then sprayed on the feed evenly and stirred and dried. After the feed is dry then mix it with vitamin $\mathrm{E}$ with a dose of Vitamin E $150 \mathrm{mg} / \mathrm{kg}$ of feed then dissolved with $2 \mathrm{ml}$ alcohol and $5 \mathrm{ml}$ water, then followed by a coating process using egg whites that have been diluted with $40 \mathrm{ml}$ of water with how to spray it into the feed and do it stirring and drying it.

Maintenance of papuyu broodfish for 20 days with commercial feed mixed with $10 \mathrm{ml} / \mathrm{kg}$ of $\beta$ glucan and Vitamin E $150 \mathrm{mg} / \mathrm{kg}$ of feed for treatment (A) and commercial feed for treatment 
(B). Feeding twice a day in the morning at 8:00 a.m. and 5:00 p.m. with a dose of 5\% of the body weight of the fish.

Somatic Gonado Index (IGS)

Gonad observations can be converted into percent, namely the Somatic Gonada Index (IGS). The IGS value will reach the maximum range limit at the time of spawning. IGS is determined using Scott's formula in Effendi (1997), namely:

$$
\mathrm{IGS}=\frac{\text { Bobot gonad }(\mathrm{g})}{\text { Bobot tubuh }(\mathrm{g})} \times 100 \%
$$

Hepato Somatic Index (IHS)

Liver observations can be converted into percent, namely the Hepato Somatic Index (IHS). The Hepato Somatic Index (IHS) is used to describe the energy reserves present in the body of the fish when the fish is experiencing development of gonad maturity. The calculation is formulated by Effendi (1997) as follows:

$$
\mathrm{IHS}=\frac{\text { Bobot hati }(\mathrm{g})}{\text { Bobot hati }(\mathrm{g})} \times 100 \%
$$

Water quality

Water quality parameters observed were temperature, dissolved oxygen (DO), degree of acidity $(\mathrm{pH})$ and ammonia (NH3).

\section{RESULTS AND DISCUSSION}

\subsection{Results}

The results of the observation of all parameters can be observed in table 1 .

Table 1. Average Value of Parameters Observed for Each Treatment.

\begin{tabular}{|ccc|}
\hline Perlakuan & IGS & IHS \\
\hline A & $0,163 \pm 0,015^{\mathrm{a}}$ & $0,0093 \pm 0,0015^{\mathrm{a}}$ \\
\hline
\end{tabular}




\section{B}

$0,055 \pm 0,027^{b} \quad 0,0096 \pm 0,003^{a}$

Source: Primary data processed (2020)

Note: Different letter signs indicate significant differences in treatment.

\section{DISCUSSION}

\section{Somatic Gonado Index (IGS)}

Addition of the dose of $\beta$-glucan and vitamin $\mathrm{E}$ in the feed so that the presence of fatty acids increases. The high levels of fatty acids cause the formation of vitellogenin during the vitellogenesis process in the liver, the faster it occurs, so that the faster it is allocated to the ovaries optimally for egg cell formation. During the process of vitellogenesis, the ovaries will absorb vitellogenin, so that the accumulation of vitellogenin occurs optimally. Optimal retention of vitellogenin causes the formation and growth of gonads to accelerate. The rapid formation and growth of gonads causes gonad weight and percentage of TKG to increase. The increase in gonad weight also causes the IGS value to increase as well. Wouters et al., (2001) stated that the change in the IGS value was due to the addition of gonad weight during growth and maturation of the gonads, while Arfah et al., (2013) stated that the increase in the IGS value was due to an increase in the amount of vitellogenin in the vitellogenesis process to be allocated. to the gonads so as to increase the IGS value.

\section{Hepato Somatic Index (IHS)}

The IHS value is inversely proportional to the IGS value, this is in accordance with the statement of Wise (2013), that the liver can be seen from changes in its energy content, where the energy levels of the liver tend to rise at the beginning of the first to third maturity of the gonads, then decrease to the final gonad maturity level TKG V). If you pay attention to the IHS value in line with the progress of ovarian development. As Wise (2012) states that the liver is an organ for storing energy reserves and will be dismantled to support the development of oocytes (egg cells), namely during the vitellogenesis process (egg yolk synthesis process).

\section{CONCLUSION}

The maintenance of papuyu broodfish (Anabas testudineus Bloch) for 20 days with feeding mixed with $\beta$-Glucan and Vitamin $E$ had a significant effect on the percentage of somatic gonado index (IGS), but had no significant effect on the hepato somatic index (IHS).

\section{REFERENCE}

Arfah, H., Melati \& M. Setiawati. 2013. Supplementation of vitamin E with different doses in feed on the reproductive performance of the female parent of comet fish (Carassius auratus auratus). J. Indonesian Aquaculture. 12: 14-18. 
Vol. 06, No. 02; 2021

ISSN: $2456-8643$

Wise. U. 2006. Preliminary bio-eco study of snakehead reproduction in the Bapai swamp, South Kalimantan Province. National Symposium on Biotechnology in Aquaculture 2006. Department of Aquaculture, Faculty of Fisheries and Marine Sciences, Bogor Agricultural University and Research Institute for Freshwater Aquaculture Research Agency for Marine and Fisheries. July $5,2006$.

Wise. U. 2010. Study of Reproductive Physiology of Cork Fish, Channa striata Blkr as Efforts to Domesticate Cultivated Commodities in Swamp Waters [dissertation]. Water Study Program. Bogor Agricultural Institute.

Bijaksana U. 2012. Dosmestication of snakehead fish (Channa striata Blkr), efforts to optimize swamp waters in South Kalimantan Province. J. Suboptimal land. 1 (1): 92-101.

Wise U. 2013. Fish Reproductive Physiology. Aquaculture Study Program. Faculty of Fisheries and Marine Affairs. Lambung Mangkurat University. Banjarbaru.

Cholik, F, Jagatraya A. G, Poernomo R. P and Jauzi A. 2005. Aquaculture. Indonesian Fisheries Society and Taman Mini Indonesia Indah. Jakarta

Effendie, M.I. 1997. Fisheries Biology. Pustaka Nusatama Foundation. Yogyakarta.

Mokoginta I, D Jusadi, M Setiawati and MA Suprayudi. 2000. The need for essential fatty acids, vitamins and minerals in the main feed of Pangasius suchi for reproduction. Competitive Grants VII / 1-2 Universities / Fiscal Year 1998/2000. Bogor Agricultural Institute. Final report.

Napitu, R., S. Limin \& Suparmono. 2013. The effect of adding vitamin E to trash fish meal based on the maturity of red tilapia gonads (Oreocromis niloticus). J. Aquaculture Engineering and Technology, 1: 110-116

Wouters R. Piguave X, Bastidas L, Calderon J, Sorgeloos P. 2001. Ovarian maturation and hemolymphatic vitellogenin concentration of pacific white shrimp Litopenaeus vannamei (Boone) fed increasing levels of total dietary lipids and HUFA. Aquaculture Research 32: 573 582. 